\title{
SHALE OIL AND GAS PROSPECTIVITY OF THE NORTHERN WESTERN DESERT, EGYPT
}

\author{
Amgad Soliman ${ }^{1}$, Mohamed Yousef ${ }^{2}$, Yasser El Safori ${ }^{2}$ \\ 1 Ieoc, Eni-Egypt branch \\ 2 Ain Shams University, Faculty of Science, Geology Department, Cairo, Egypt
}

\begin{abstract}
Since the first hydrocarbon discovery in the Western Desert in 1969, several papers were published focusing on the conventional petroleum system elements. The entire stratigraphic section was studied to define the source rocks, seals and reservoirs. The present work focuses on screening the available dataset and re-using the geological information to assess the possible unconventional hydrocarbon resources. Geochemical analyses of the hydrocarbon rich stratigraphic intervals could lead to define and rank the shale oil and gas plays in terms of their presence, type, quality and lateral extension. Both major source rocks(Abu Roash and Khatatba formations) went through many geological and geochemical studies that proved their efficiency and ability to produce oil, gas, and condensate in different localities based on their maturation, total organic content, hydrogen index and kerogen type. Preliminary screening of the stratigraphy and geochemistry of the Western Desert source rocks indicated the shale gas and oil potential of the Abu Roash source rock in the Abu Gharadig Basin. The parameters required to assess the shale oil/gas plays are depth, thickness, lithological content, total organic content and maturation. In this paper, the available geochemical data were collected, screened and plotted to indicate the possible unconventional hydrocarbon plays.
\end{abstract}

Keywords: Unconventional, Shale oil, Shale gas, source rocks, Western Desert, Abu Gharadig Basin.

\section{INTRODUCTION}

The present paper uses the available published geochemical data to define the shale gas and oil potential in different localities of the Western Desert of Egypt. Several publications discussed the fundamental measurements of TOC, maturity and Kerogen type. In Shoushan Basin, Ramadan et al. (2012) studied the geochemical analyses of wells in Tut oil field; whereas these analyses were carried out in Salam oil field by Abdel Gawad et al. (2017). Younes (2005) conducted geochemical analyses as well of Shoushan-1X well, while Metwalli and Pigott (2005) studied Louly well, and Shalaby et al. (2008) studied Shams wells. In Abu Gharadig Basin, geochemical data of the wells (Sit 1-1, Sit 2-1, Sit 4-1, Sit 71, BED 3-3, BED 3-4, BED 3-10 and Bed 17-1) were obtained from (Awad, 2008), Sheiba 18-1 from (Moretti etal., 2010), Abu Gharadig1,2,3 and 4 from (Khaled, 1999), additional data for Abu Gharadig-1 from (El Nady 2016), GPT-3 (Hamed, 1999), GPT SW-7 (El Beialy, 2010).

A conventional source rock could be considered as shale oil or shale gas bearing strata if they are partially retaining part of the generated hydrocarbons. The unconventional potential of a source rock could be measured calculating the generated hydrocarbon volumes minus the expelled ones. If this shaly source rocks interval still includes considerable percent of silica and carbonate grains, they are able to be hydraulically fractured for releasing the entrapped hydrocarbons.

Several parameters have to be verified to assess the unconventional shale oil/gas play; out of them: depth, thickness, kerogen type, TOC and maturity. Such parameters need to be compared with the producing shale gas/oil fields in North America. The data obtained from the discovered shale plays in the USA indicate difficulties in case of exceeding the depth of $3500-4000 \mathrm{~m}$. Such drilling depth will face operational problems in the drilling and hydraulic fracturing process. Furthermore, the cost will be higher 
Soliman, et al.

knowing that the shale development process requires the drilling of large number of wells ( 4 or 8 wells per square mile).

Drilling of several horizontal wells from the vertical holes is mandatory to recover the gas and oil contained in the shale rocks. Knowing that many of these strata are dipping or not laterally distributed with minimum thicknesses of $10 \mathrm{~m}$ and $30 \mathrm{~m}$ is a must to develop the shale oil and gas strata respectively. Such thicknesses allow the horizontal drilling (geo-steering) to track them horizontally. The lithological contents of the shale play have a significant value for the ability of rock to make continuous permeable network by the hydraulic fracturing process. Shale of clay content exceeding $30 \%$ is elastic and restores its form after the fracturing process. It is favorable to have carbonate or silica content with the clay minerals to make the rock passing successful fracturing operation.

The geochemical characterizations of a source rock are fundamental to make it a potential shale play. It should be in the oil/condensate or gas play as per today's thermal maturity window. Kerogen type II is much preferred to have an active source rock with the possibility to give oil, gas and condensate. The total organic carbon (TOC) is known as the organic richness as it gives the value of expected generated hydrocarbon volumes. In the shale gas plays the higher TOC values have additional value as the kerogen can adsorb the gas on its surface. The calculated hydrocarbon in place indicates basically the gas stored in the pores of the shale. Additional volumes are adsorbed by the kerogen particles. Geological framework in terms of stratigraphy, sedimentology and geochemistry of the Western Desert were studied and published by the Egyptian General Petroleum Corporation (EGPC, 1992).The tectonostratigraphy of Abu Gharadig and Fayum basins recognized three main depositional cycles which are the Hercynian, Late Jurassic to Early Tertiary and from Late Cretaceous to Middle Tertiary. The study included geothermal mapping and hydrocarbon potential for the possible source rock intervals (Awad, 1984).

Crude oil samples and well cuttings from Abu Roash-F and Khatatba formations were studied and presented two main petroleum systems of Late Cretaceous marine shales and Jurassic- Early Cretaceous non-marine organic-rich shales. Another third possible hydrocarbon system is a mixture of both source rocks (El Diasty and Moldowan,2012).In addition to the previously mentioned publications the source rock potential and the hydrocarbon generation of the northern Western Desert of Egypt were studied by many authors, among them are: Zein El- Din and El-Hamzy (1980), Parker (1982), Shahin and Shehab (1988), Zein El-Din et al.(1990), Abdel-Kireem et al. (1995), Ibrahim (1996), Abdel-Gawad et al.(1996), Douban (1996),Metwalli et al. (1999), Dolson et al.(2000), Darwish et al. (2000) and Waly et al. (2001), Maky and Ramadan (2008), Awad (2008), Moustafa (2008), El Beialy (1994, 1995), Moretti et al. (2010), Zobaa et al. (2011).

\section{STRATIGRAPHY}

The stratigraphic succession of northern Egypt is characterized by several carbonate-clastic alternations. Together with the enclosed secondary transgressive-regressive cycles (Fig.1), it constitutes one of the main elements of the Mesozoic-Early Tertiary petroleum system of the Western Desert. This is because the N-S facies zonation and vertical cyclicity brought about the interlayering of potential source, reservoir and seal facies in the Mesozoic sequence. The other two elements, the Late Jurassic to Late Cretaceous basin subsidence and Late Cretaceous-Paleocene deformation, contributed, respectively, to the localization of generative basins and to trap formation (Keeley, 1989; Jenkins, 1990; Klitzsch, 1990; Said,1990; Keeley and Wallis, 1991;Dahi and Shahin, 1992).

Paleozoic rocks (the Cambrian-Silurian Siwa Group and the Devonian-Carboniferous Faghur Group) are the thickest in the Western part (Siwa area: 2750-3000m); mostly continental to shallow marine sandstones, siltstones and shales, with thin intercalations of Middle-Late Jurassic sedimentary rocks extend across North Egypt, from the exposures of North Sinai to the Western Desert subsurface. They attain a total thickness of 2000-3500m with E-W main depocenters in the east and north. The discontinuous Early- Middle Jurassic Bahrein coarse sandstones $(0-550 \mathrm{~m})$ partly are a lateral equivalent and partly disconformably overlain by the Khatatba Formation $(390-1375 \mathrm{~m})$. Bahrein sediments are predominantly lagoonal in Sinai, with carbonaceous shales, coal, sandstones, marine shales, and siltstones. Sandstones and some carbonates occur towards southwest. It is overlain by Oxfordian to Kimmeridgian 


\section{Shale oil and gas prospectivity of the northern Western Desert}

transgressive shallow marine shelf carbonates (Masajid Formation, 200-400 m to $570-840 \mathrm{~m}$ in depocenters). Early Cretaceous sandstones (mainly fine- to coarse-grained and quartzose) unconformably onlap the eroded top of the Jurassic rocks. They are continental or deltaic-fluviatile and occasionally contain dolomite and anhydrite beds (Alam el Bueib Formation, 500-2000m). The widespread Middle Aptian marine transgression is represented, in the north, by the lagoonal to supratidal Alamein Dolomite (few tens to $80 \mathrm{~m}$ ), an excellent stratigraphic and seismic marker and locally an important reservoir in the south and southwest (the Abu Ballas marine sands and shales (EGPC, 1992). The overlying Kharita Formation sandstones $(350$ to $>800 \mathrm{~m}$ ) are regressive. The Late Cretaceous marine cycles include the Bahariya (300-480 m, Early Cenomanian) fine- to very fine-grained shallow marine sandstones, a widespread oil play, and the Late Cenomanian-Turonian Abu Roash Formation, characteristically an alternation of dolomitized limestones, shale, and sandstones (the carbonates become more abundant and thicker northwards). The formation is subdivided into seven (A-G) members; several of these are important reservoirs and source rocks, especially in the Abu Gharadig Basin. There, the formation, usually 250-750 m thick, attains a thickness of almost $1000 \mathrm{~m}$.

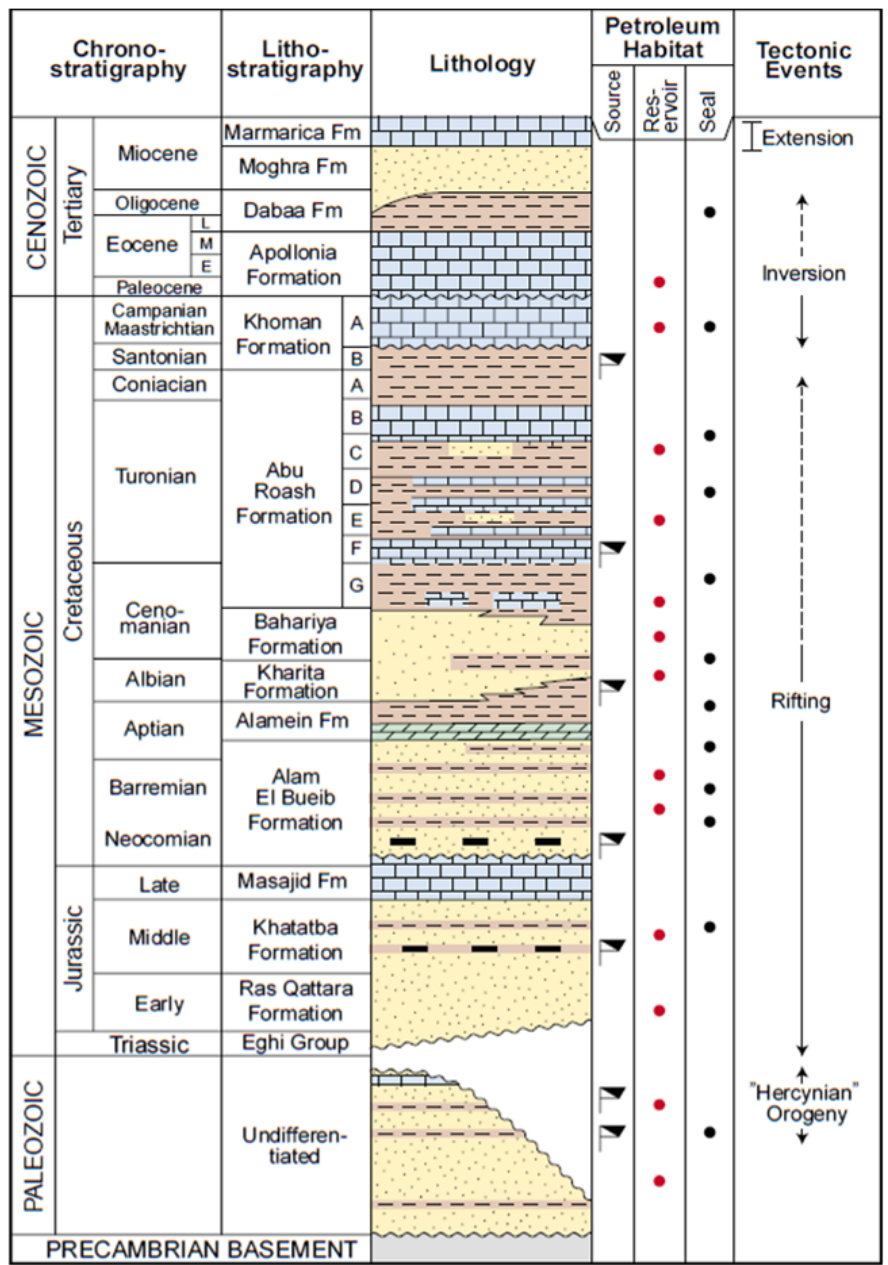

Senonian-Paleocene facies include chalk, marl, argillaceous limestone, bedded chert, often with a high content of bituminous organic matter, representing widespread marine deposition with high sea level stands extending southeastwards in Egypt as embayment over the present Nile Valley (EGPC, 1984). The impact of Senonian tectonic movements is seen in thickness variations, stratigraphic gaps and unconformable relations. Senonian beds are thin or missing on uplifts and show multiple levels of onlap and angular unconformities. Most important are the Khoman (few tens to $1650 \mathrm{~m}$ ) and the Apollonia formations (Paleocene-Middle Eocene chalky to nummulitic limestones, generally 100m, 550 to $1675 \mathrm{~m}$ in depocenters). The top of the Western Desert stratigraphic sequence is mostly formed by terrigenous clastics, the Late Eocene-Oligocene Dabaa Formation (200-400 m, max. $825 \mathrm{~m}$ ) is formed of marine 
Soliman, et al.

shales, and the Late Oligocene to Early Miocene Moghra Formation (200-970 m, is mainly sandstones, fluvio-marine, lagoonal to shallow marine upwards). Then the succession ends up with The MarmaricaFormation (up to $150 \mathrm{~m}$ thick alternating limestones and dolostones).

\section{STRUCTURAL SETTING}

The Western Desert can be divided into several large-scale structural provinces (Fig. 2), which developed preferentially along pre-existing lines of weakness in the basement and in response to lateral movements between Europe and Africa (EGPC, 1992).In general, the Western Desert is characterized by a northwestward thickening Paleozoic section and northward thickening prism of Mesozoic and Tertiary strata which are interrupted by the major east-west trending Sharib-Sheiba high (EGPC, 1992). This regional uplift separates the Abu Gharadig, Natrun and Gindi basins from the coastal northernWestern Desert basin. This basin could be divided into a group of sub-basins (EGPC, 1992). The Kattaniya High is a horst block in the eastern part separating the Natrun Basin from the Gindi Basin (EGPC, 1992). The Gindi Basin, at least at times, is an eastward extension of the Abu Gharadig Basin (EGPC, 1992).

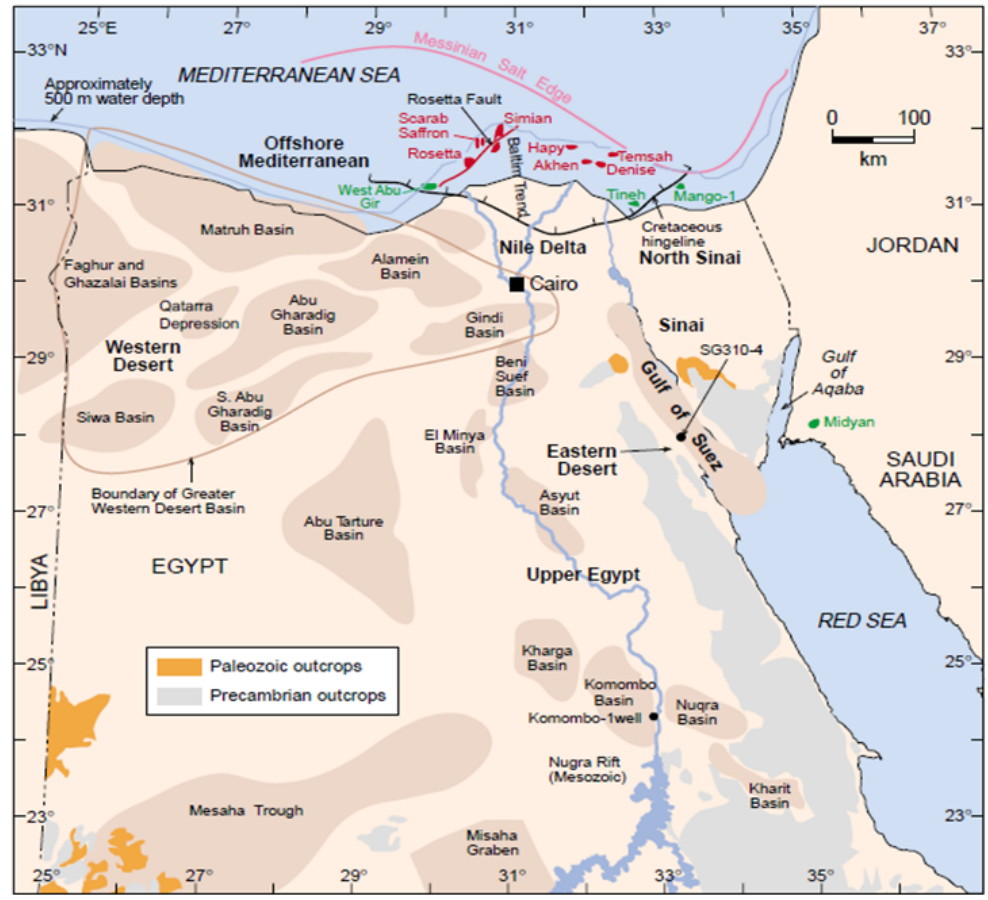

Fig. 2: Western Desert's sedimentary basins (after Dolson et al., 2000).

The sedimentary basins of the Egyptian Western Desert havebeen developed through eight tectonic and magmatic events (Guiraud et al., 1992). These events are as follows:

a. Permo-Triassic rifting associated with Late Triassic-Early Jurassic magmatism.

b. Neocomian-Early Aptian rifting.

c. Aptian-Albian rifting (associated with the extrusion of alkaline and transitional basalts).

d. Santonian compressive event (Santonian event).

e. Cenomanian-Early Eocene sagging and basin deepening.

f. Intra-Eocene compression.

g. Late Eocene compression.

h. Neogene igneous activity.

\section{UNCONVENTIONAL RESOURCES}

\section{Shoushan Basin}

Major hydrocarbon discoveries in Shoushan Basin confirmed that shales of the Khatatba Formation are the main source rock of the basin. Abu Roash TOC rich strata lie mainly in the immature thermal hydrocarbon zone without significant role in the petroleum system. The Jurassic Khatatba source rock had 
Shale oil and gas prospectivity of the northern Western Desert

charged oil and gas for the reservoirs in the entire stratigraphic section of Khatatba, Alam El Bueib, Kharita, Bahariya and Abu Roash formations.

The studied wells in Shoushan basin (Fig. 3) are Shoushan-1, Louly-1, Shams-2, Shams NE-1, Salam2, Salam-5, Salam-35, Salam-52, and Tut-21-Deepwells.

Fig. 3: Reference wells studied in Shoushan Basin.

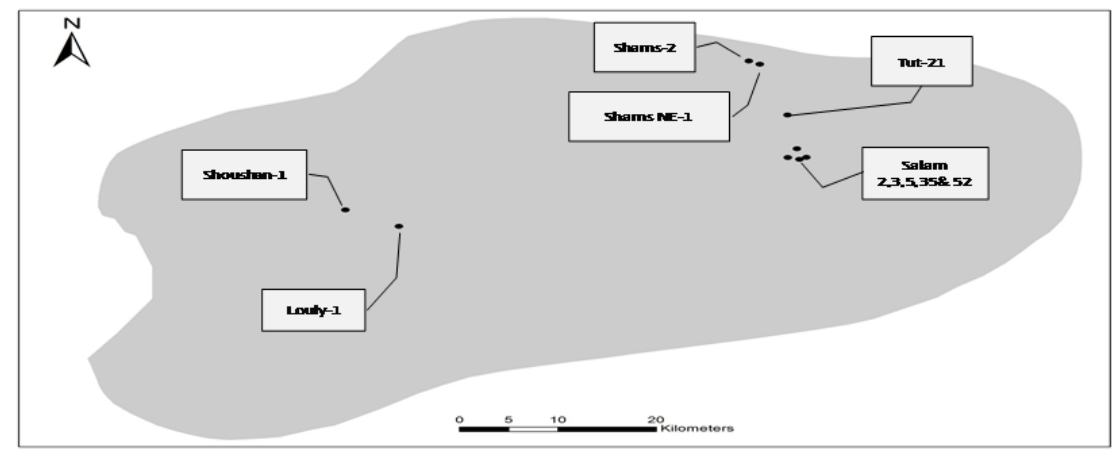

\section{TOC}

The ten studied wells (Figs. 4 to 8 ) shows TOC values for Abu Roash source rock up to $2.63 \mathrm{wt} \%$ in Salam field wells $(2,5,16,35$, and 52). TOC values for Alam El Bueib Formation are up to $6.92 \mathrm{Wt} \%$ in Shmas NE-1 well, while TOC values for the Khatatba source rock are up to $8.61 \mathrm{wt} \%$ in Shmas NE-1 well. The data of the studied wells are shown in Table 1.

Table1. TOC limits for the studied wells in Shoushan Basin.

\begin{tabular}{|c|c|c|c|c|c|c|}
\hline strata $\backslash$ well & Shoushan-1X & TUT 21 & $\begin{array}{c}\text { Salam } \\
2,5,16.35 .52\end{array}$ & Salam 3 & Shams 2X & Shams NE 1 \\
\hline Abu Roash G & 1.5 & & $1.57(2.63)$ & & $0.36(0.79)$ & $0.39(0.65)$ \\
\hline Alam El Bueib & 2.4 & $1.2(3.6)$ & & & $0.39(0.77)$ & $0.91(6.92)$ \\
\hline Khatatba & 4.2 & & & $2.31(4.27)$ & $1.42(3.43)$ & $2.83(8.61)$ \\
\hline
\end{tabular}

Values are average TOC in $\mathrm{wt} \%$. Values in brackets are the maximum values when available.

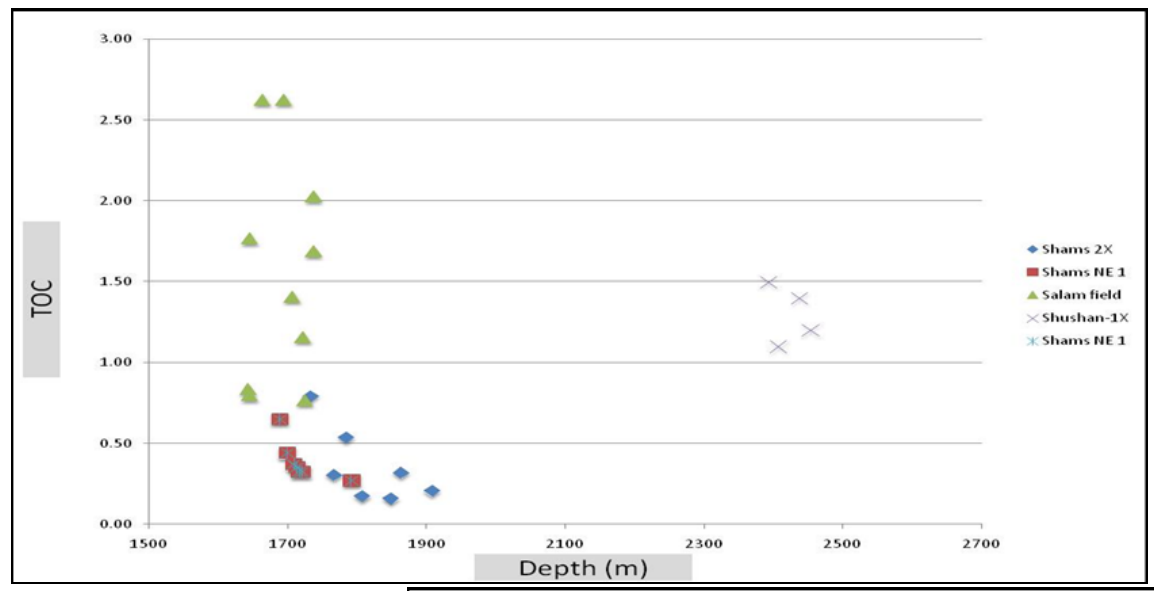

Fig. 4: TOC limit for

Abu Roash Formation in Shoushan Basin.

Fig. 5: TOC

values for

Khatatba

Formation in

Shoushan Basin

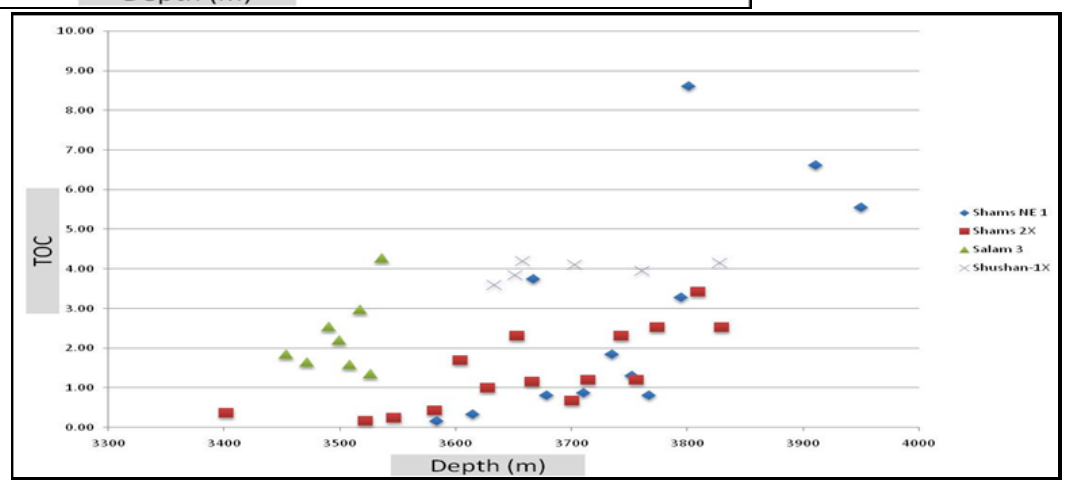


Soliman, et al.

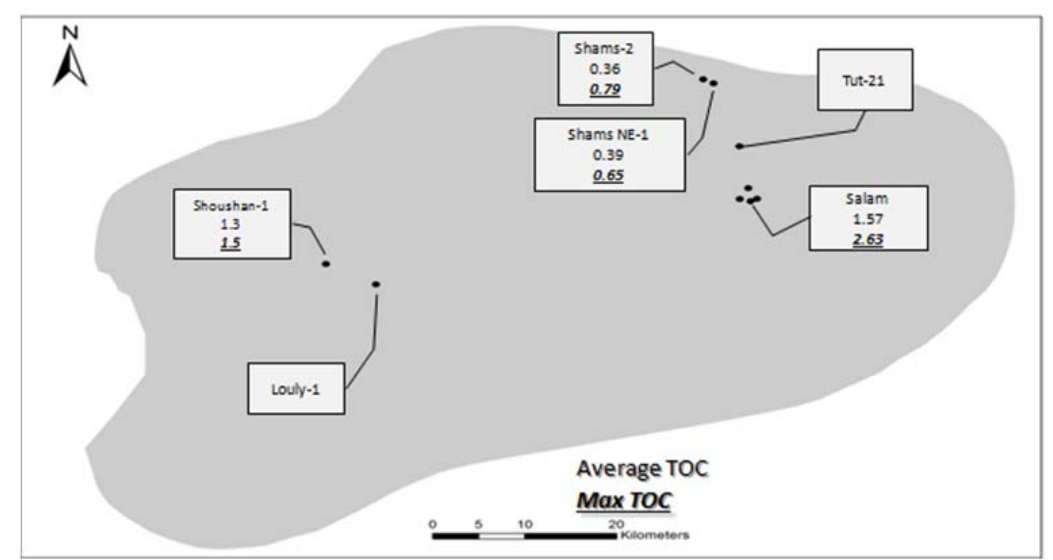

Fig. 6: TOC limits (wt \%) for Abu Roash Formation in Shoushan Basin.

Fig. 7: TOC limits (wt\%)for Alam El Bueib Formation in Shoushan Basin.
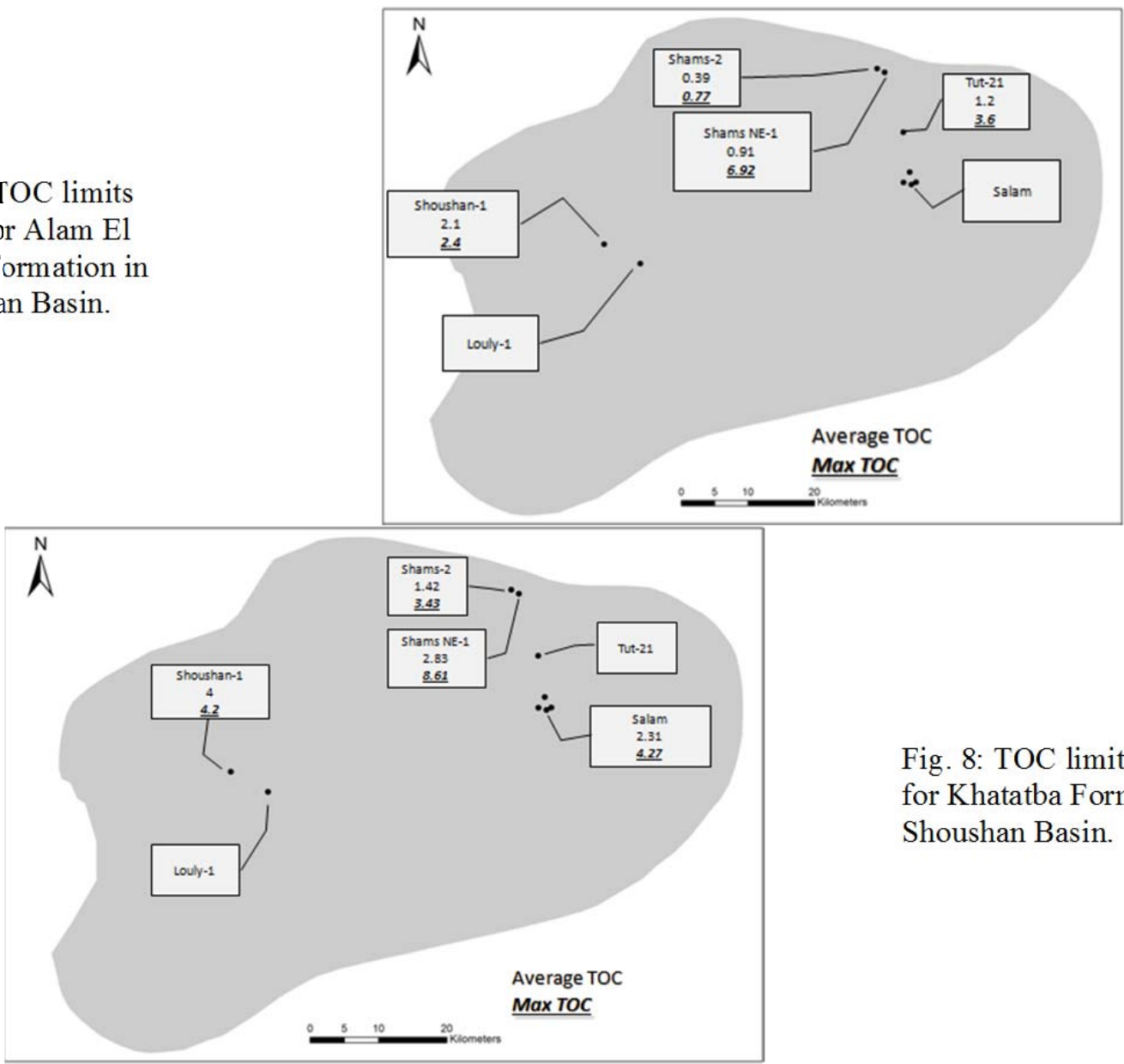

Fig. 8: TOC limits (wt.\%) for Khatatba Formation in Shoushan Basin.

\section{Thermal Maturity}

The thermal maturity of organic material is a process controlled by both temperature and time (Waples, 1994). The vitrinite reflectance is used to predict hydrocarbon generation and maturation. The data of vitrinite reflectance (Ro \%) measurements for the studied wells were plotted against depth to indicate the phases of hydrocarbon generation and expulsion based on the maturity profile. Thermal maturity was checked in five wells located in the Shoushan Basin (Figs. 9 to13). The organic rich Abu Roash Formation was found at depth ranging from 950 to $2200 \mathrm{~m}$ and its thermal maturity ranges from immature to oil window. Meanwhile, the Alam El Bueib Formation was found at depth rangingfrom1950 to 3300mand its thermal maturity ranges from oil to gas windows. Khatatba Formation is found at depth rangingfrom 3100 to 4500 mand itsthermal maturity is mainly in the gas window. 
Shale oil and gas prospectivity of the northern Western Desert

\section{Kerogen type}

Kerogen types are distinguished using the hydrogen index (HI) versusoxygen index (OI) on the modified Van Krevelen diagram originally developed to characterize kerogen types (Fig. 9). Selected samples for Shoushan-1X well were studied by Younes (2005). The studied shale source rock intervals of Khatatba, Alam El-Bueib, and Abu Roash-G from Shoushan-1Xwell contain mixed kerogen types II-III. This kerogen type of mixed vitrinite-inertinite is derived from land plants and preserved remains of algae (Peters and Cassa, 1994). Mixed kerogen type characterizes mixed environment containing admixture of continental and marginal marine organic matter and has the ability to generate oil and gas (Hunt, 1996).

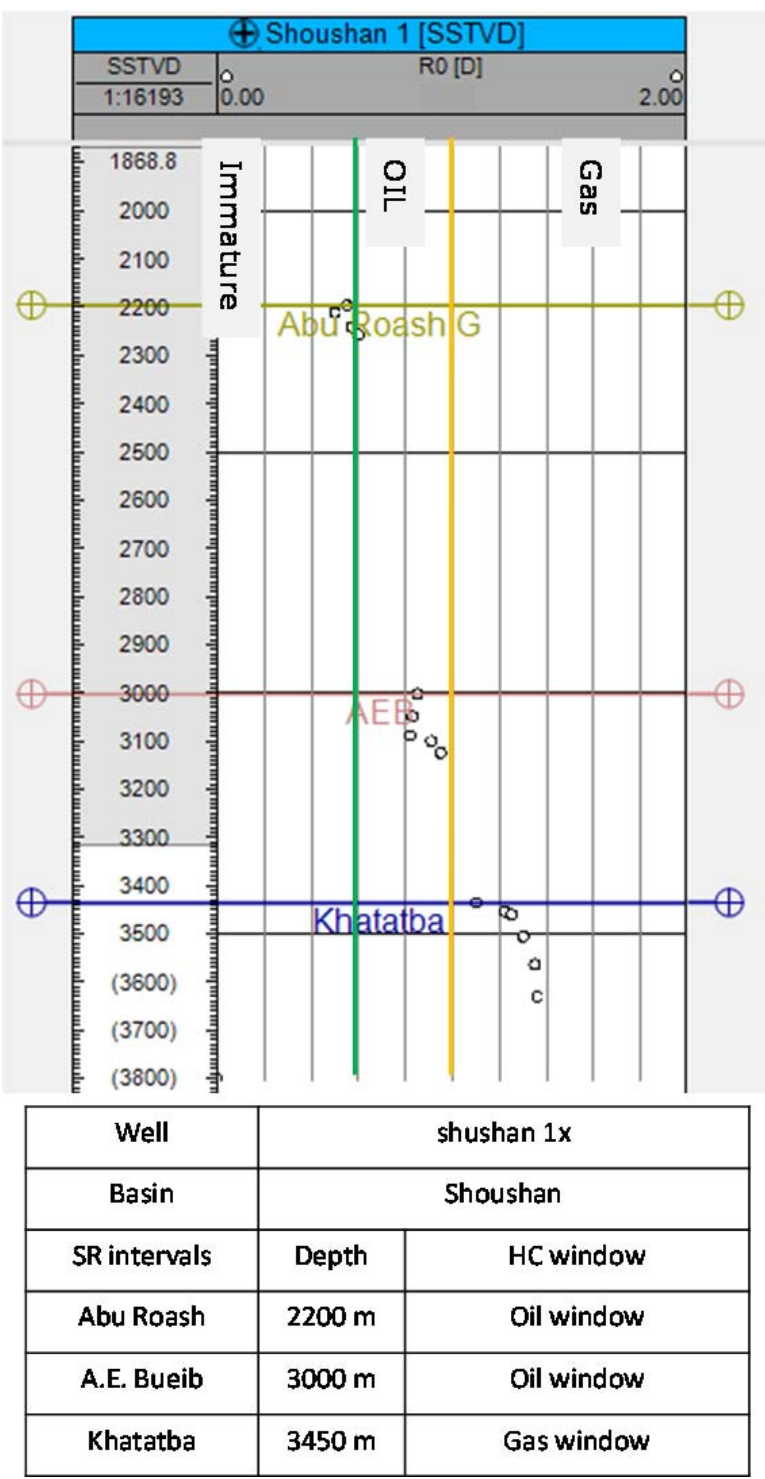

Fig. 9. Thermal maturity of Shoushan-1X well.

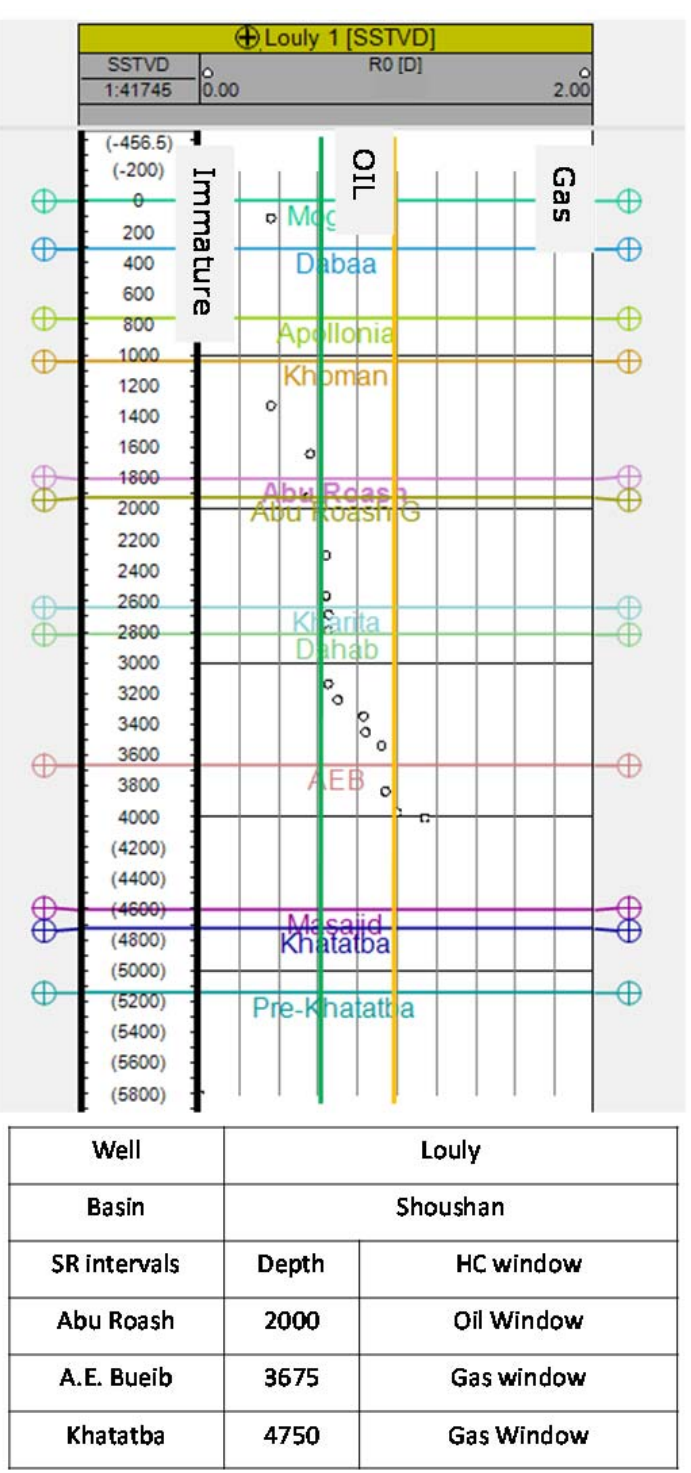

Fig.10. Thermal maturity of Louly well.

\section{Abu Gharadig Basin}

Current understanding of the Abu Gharadig Basin confirmed two main source rock bearing intervals in Abu Roash and Khatatba formations. The main oil-generating system is based on the Cretaceous Abu Roash Formation source beds, which have supplied oil to reservoirs in the Kharita, Bahariya and Abu Roash formations. Meanwhile, the older and deeper Khatatba source beds had generated oil and gas and charged the entire younger reservoirs of Khatatba, Alam El Bueib, Kharita, Bahariya and Abu Roash formations. 
Soliman, et al.

The used dataset of Abu Gharadig Basin (Fig. 15) includes Abu Gharadig-1, Abu Gharadig-2, Abu Gharadig-3, Abu Gharadig-4, BED17, BED3-3, BED 3-10, Sitra 17-1, Sitra 1-1, Sitra 5-1, Sitra 4-1, Sitra7-1, GPT-3, and GPT SW-7 wells.

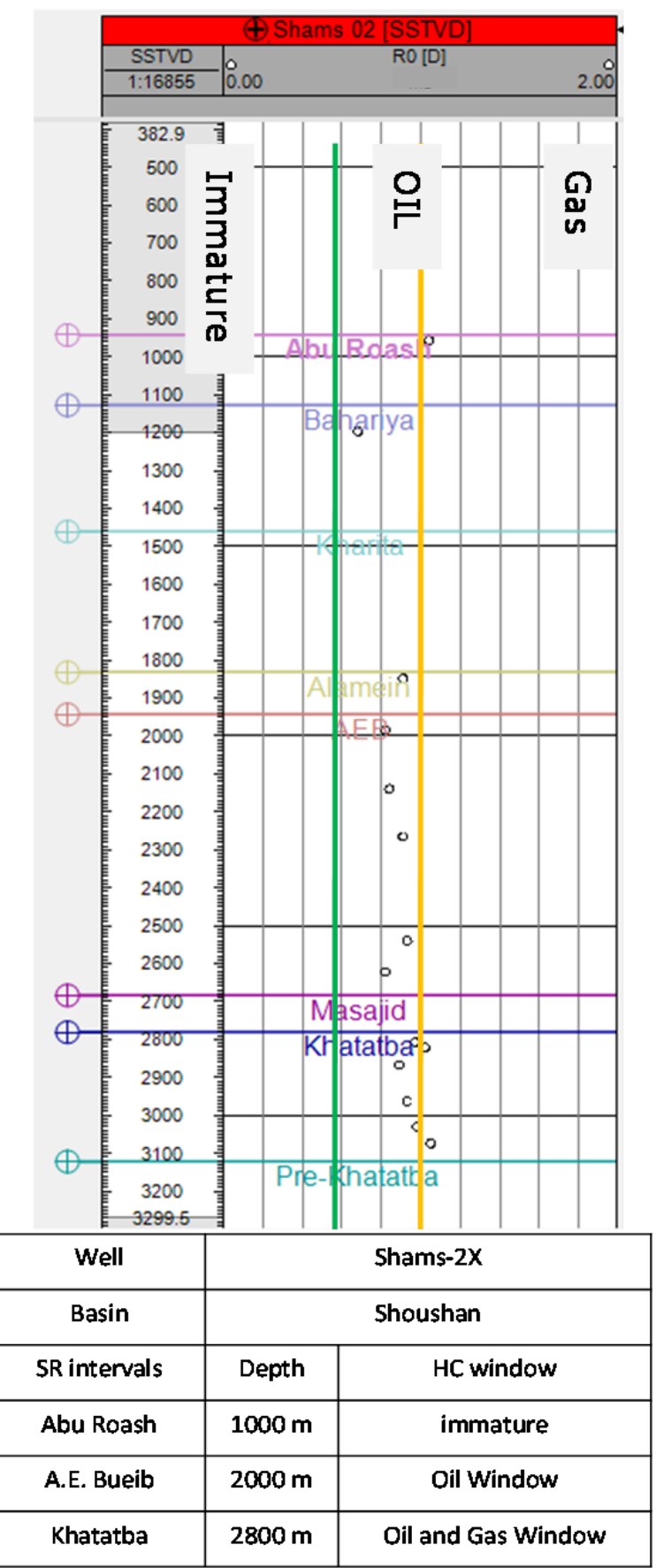

Fig.11: Thermal maturity of Shams-2 well.

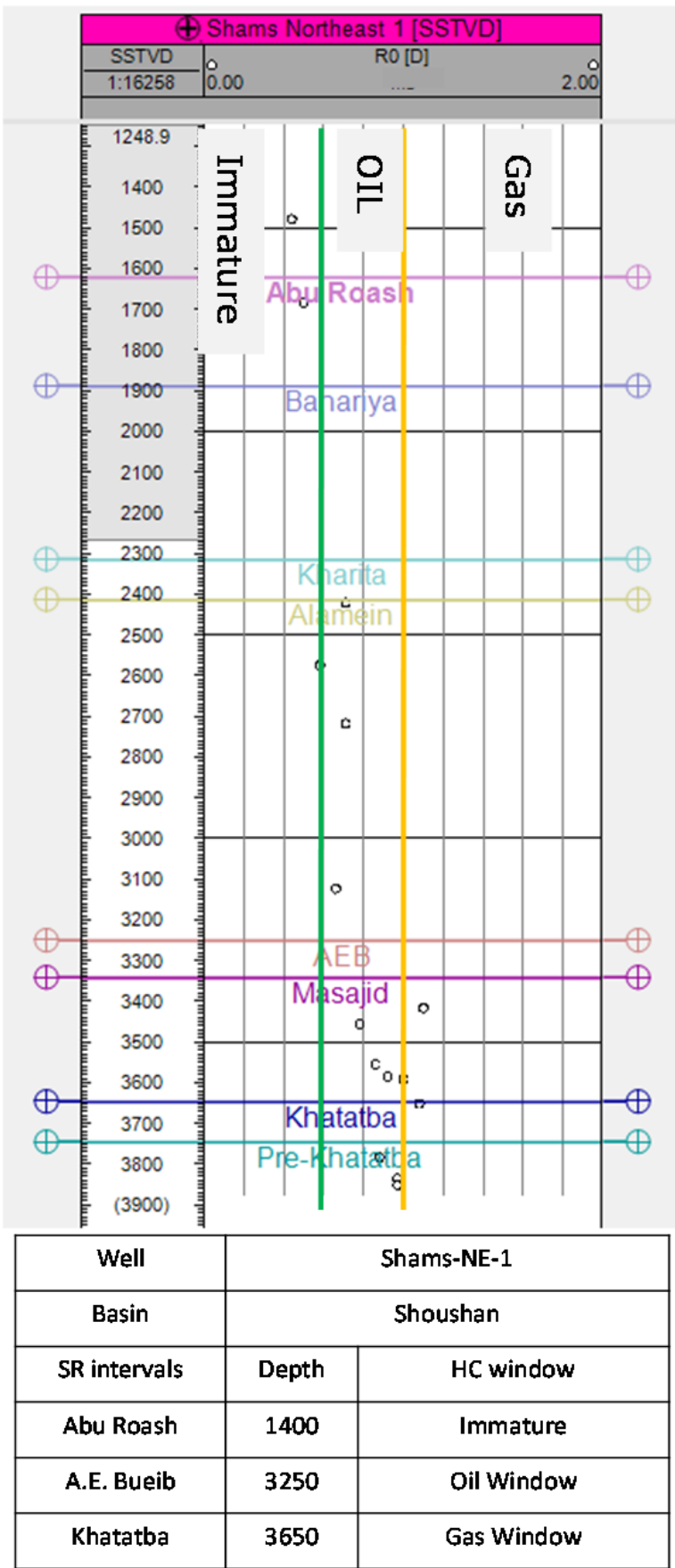

Fig.12: Thermal maturity of Shams NE-1 well.

\section{TOC}

Fourteen wells were investigated (Figs. 16 to 20) and found TOC values for Abu Roash source rock up to $3.17 \mathrm{Wt} \%$ in GPT SW-7 well. TOC for Alam El Bueib Formation has values up to $2.43 \mathrm{wt} \%$ in Sheiba18 well. Measurements of TOC in Khatatba source rock are up to 4.97 wt \% in SIT 4-1 well. Table 2 shows the studied wells. 
Shale oil and gas prospectivity of the northern Western Desert

Table 2. TOC limits for the studied wells in Abu Gharadig Basin.

\begin{tabular}{|c|c|c|c|c|c|c|c|c|c|c|c|c|c|c|}
\hline Strata / well & Sheiba 18 & $\begin{array}{c}\text { Abu } \\
\text { Gharadig } 1\end{array}$ & $\begin{array}{c}\text { Abu } \\
\text { Gharadig 3 }\end{array}$ & $\begin{array}{c}\text { Abu } \\
\text { Gharadig 4 }\end{array}$ & GPT 3 & GPT SW-7 & Sit 1-1 & Sit 2-1 & Sit 4-1 & sit 7-1 & BED 3-3 & BED 3-4 & $\begin{array}{c}\text { BED 3- } \\
\text { 10 }\end{array}$ & BED 17-1 \\
\hline Abu Roash A & & & & & & $0.82(1.01)$ & & & 0.61 & & & & & \\
\hline Abu Roash B & & & & & & & & & & & & & & \\
\hline Abu Roash C & & & & & & $0.71(0.9)$ & & & & & & & & \\
\hline Abu Roash D & & & & & $0.9(1.2)$ & $0.44(0.53)$ & & & & & & & & \\
\hline Abu Roash E & $0.38(0.5)$ & $0.88(0.98)$ & $1.2(1.56)$ & & $1(1.2)$ & $0.7(0.74)$ & & & & & & & & \\
\hline Abu Roash F & $0.82(1.59)$ & & & & $1.1(1.1)$ & 3.17 & 1.5 & & 2.5 & & 2.5 & & 2.5 & 2.67 \\
\hline Abu Roash G & $0.58(1)$ & & $1.26(1.37)$ & $1.36(1.41)$ & $1(1.2)$ & $0.81(0.94)$ & & 0.98 & 1.25 & 1.25 & 1 & & & \\
\hline Alam Fl Bueib & $1.01(2.34)$ & & & & & & & & & & & & & \\
\hline Khatatba & $1.58(3.21)$ & & & & & & 3 & 1.81 & 4.97 & & & 1.48 & & \\
\hline
\end{tabular}

Values are average TOC in wt $\%$. Values in brackets are the maximum values when available.

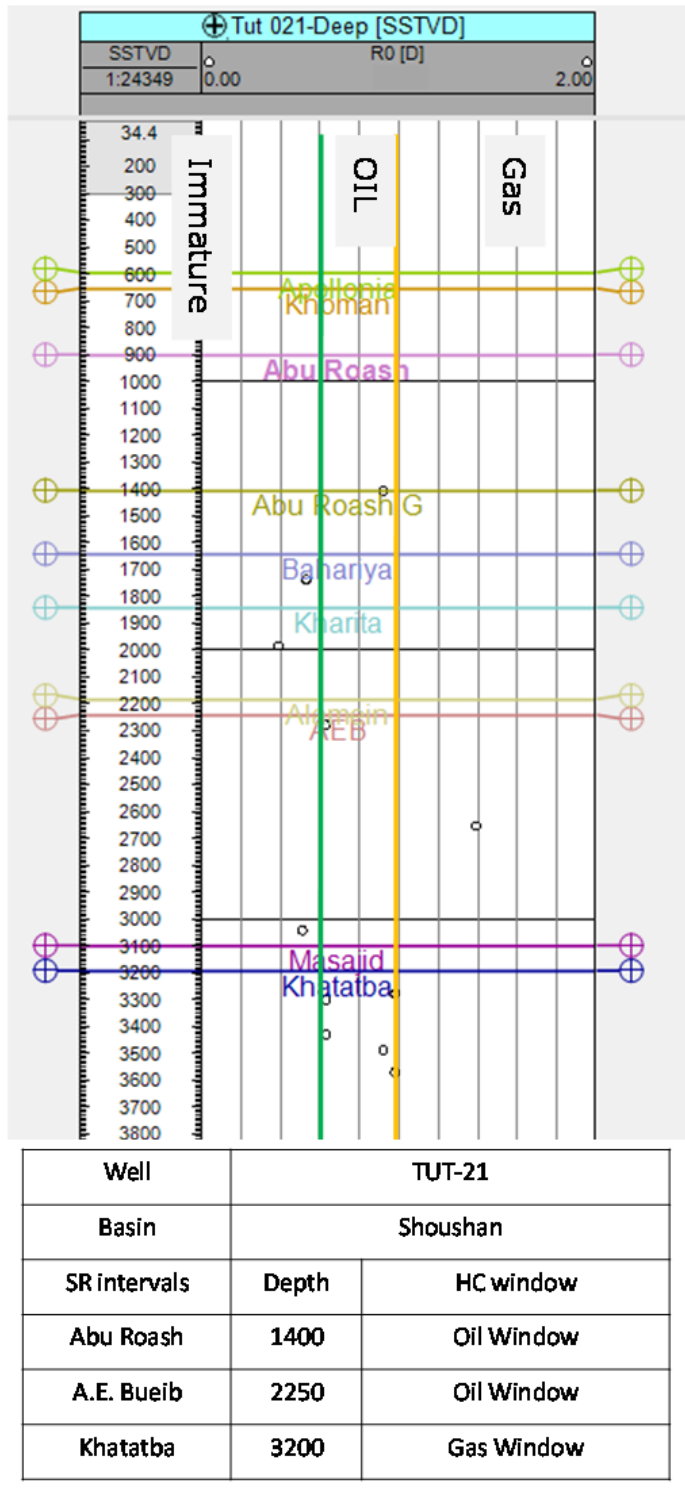

Fig.13: Thermal maturity of Tut 21-Deep well. 
Soliman, et al.

Fig. 14: Kerogen types of different source rock intervals in Shoushan1X (after Younes, 2005).
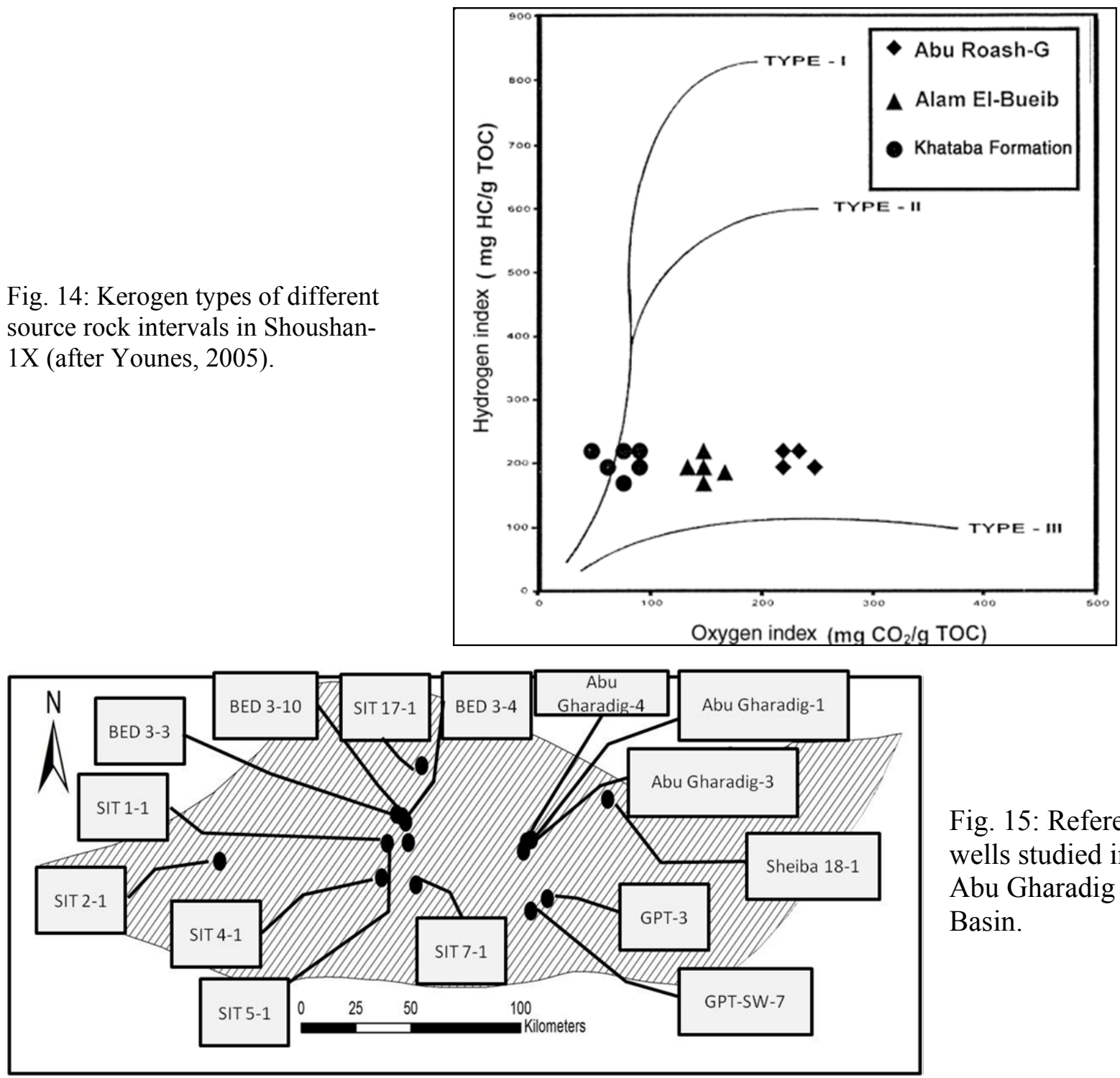

Fig. 15: Reference wells studied in Abu Gharadig Basin.

Fig.16: TOC limits for $\mathrm{Abu}$ Roash

Formation in Abu Gharadig Basin.

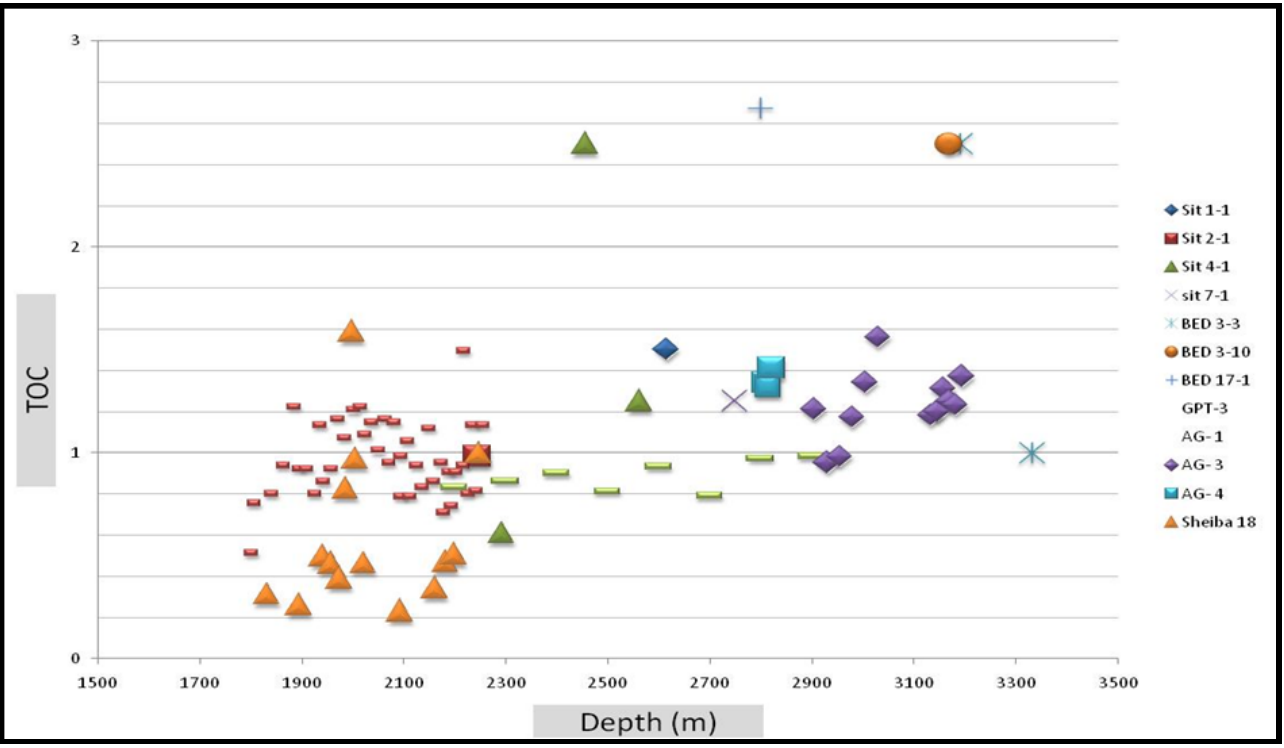


Shale oil and gas prospectivity of the northern Western Desert

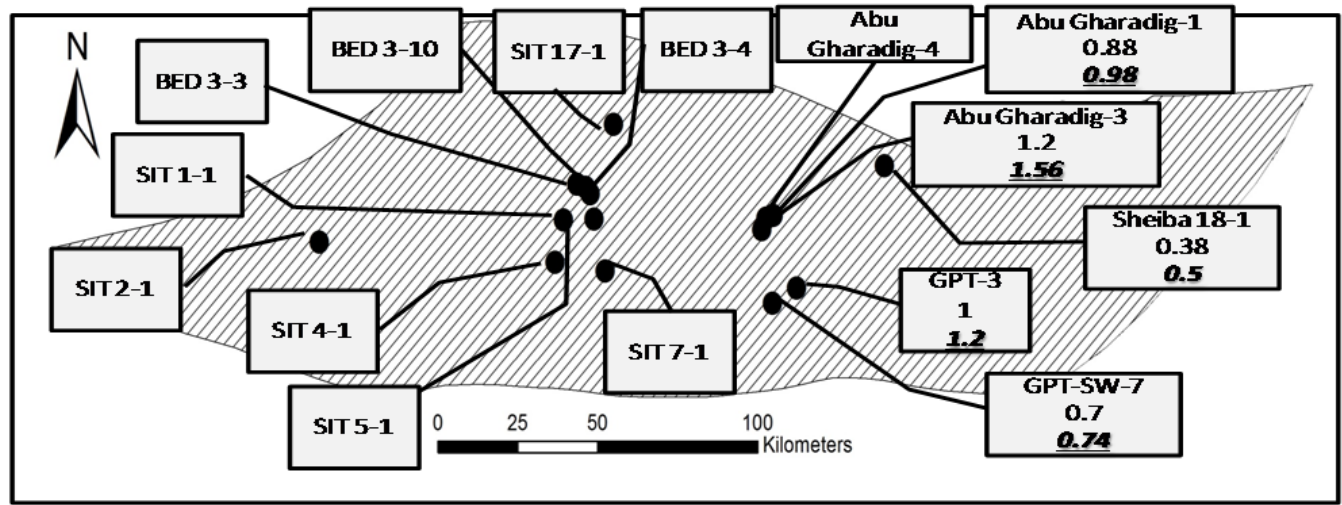

Fig. 17: TOC limits for Abu Roash-E member in Abu Gharadig Basin.

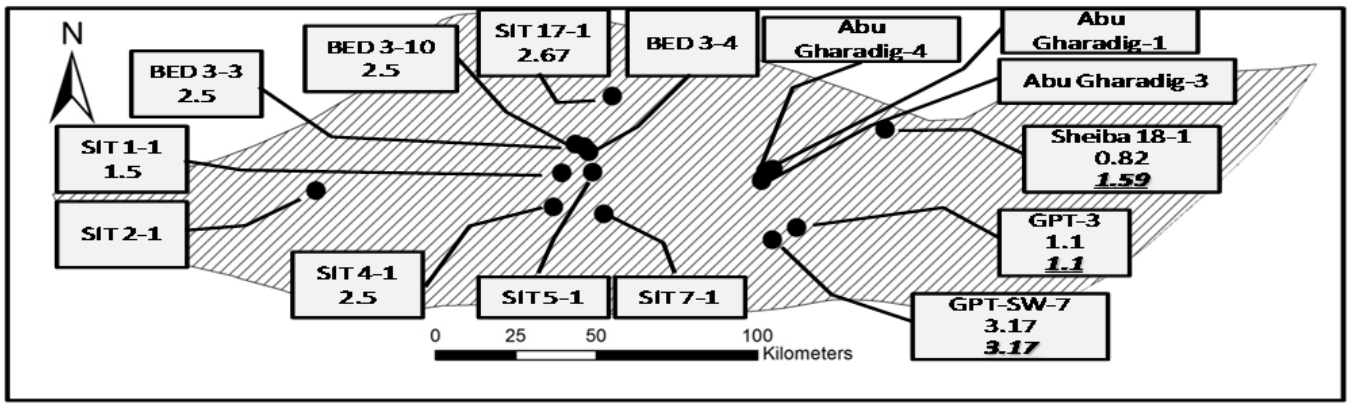

Fig. 18: TOC limits for Abu Roash-F member in Abu Gharadig Basin.

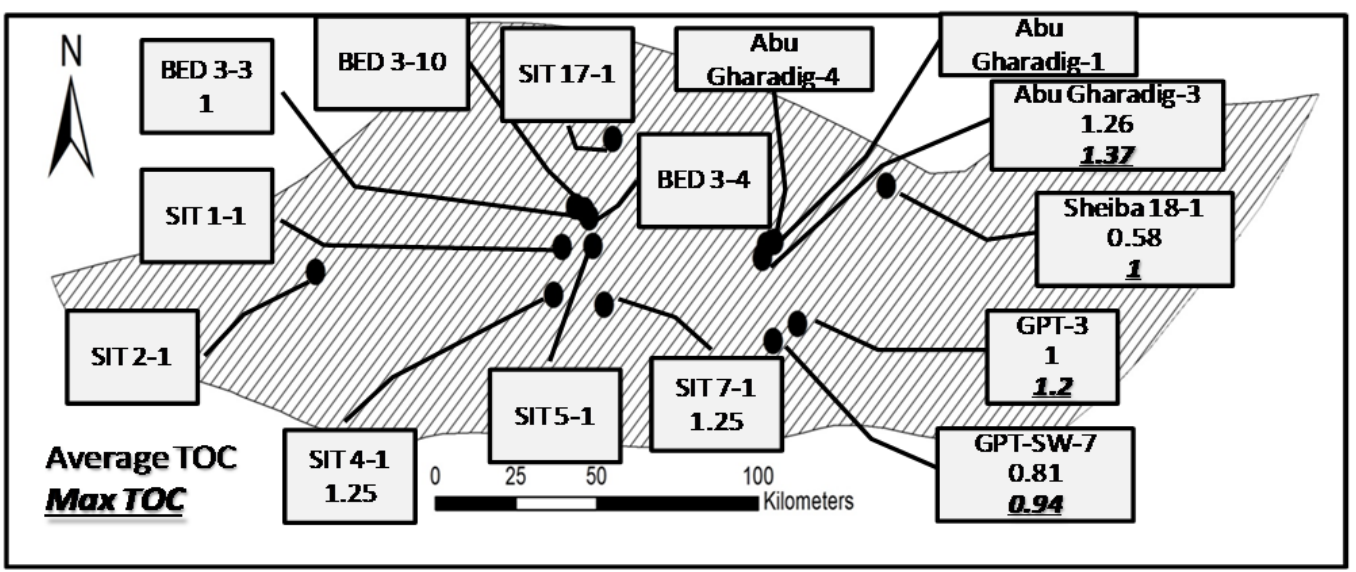

Fig.19: TOC limits for Abu Roash-G member in Abu Gharadig Basin.

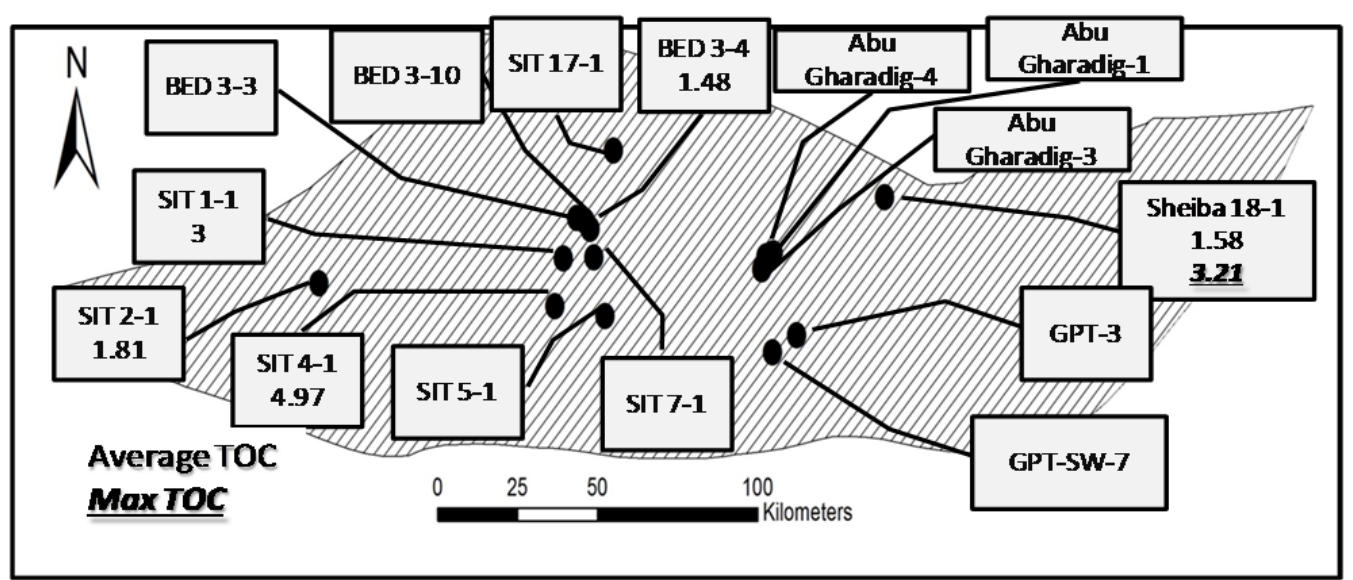

Fig. 20: TOC limits for Khatatba Formation in Abu Gharadig Basin. 
Soliman, et al.

\section{Maturity}

Thermal maturity was checked in nine wells located in the Abu Gharadig Basin (Figs. 21 to 23). The organic rich Abu Roash Formation was found at depth ranging from 2200 to 3400mand its thermal maturity ranges from immature to oil or gas windows. Extrapolation of the maturity data downwards shows that the Alam El Bueib and Khatatba source rocks are located at depth ranging from gas to overmature windows.

\section{Kerogen analyses}

Elemental analysis of samples from the Abu Roash E and G members done by Khaled (1999) gave $\mathrm{H} / \mathrm{C}$ (Hydrogen/Carbon) ratios ranging from 0.73 to 1.06 , and $\mathrm{O} / \mathrm{C}$ (oxygen/Carbon) ratio between 0.038 and 0.060 . This indicates a sapropelic oil-prone type II kerogen, of high oil source potential (Baskin, 1997), which is in the principal zone of oil generation. Optical analysis showed that the organic matter is mainly composed of marine amorphous sapropelic material (about 70\%), together with structured liptinite (exinite) macerals (about 30\%).

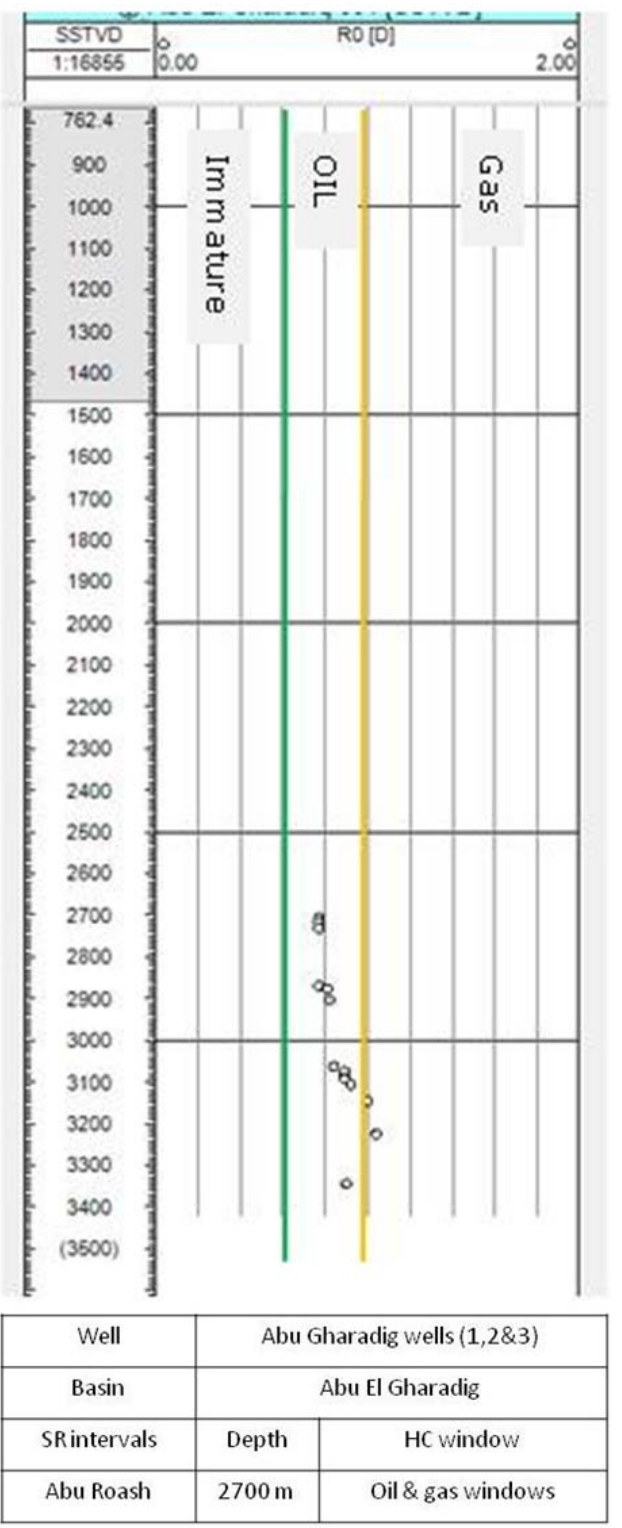

Fig. 21: Thermal maturity combining Abu Gharadig1, 2, and 3 wells.

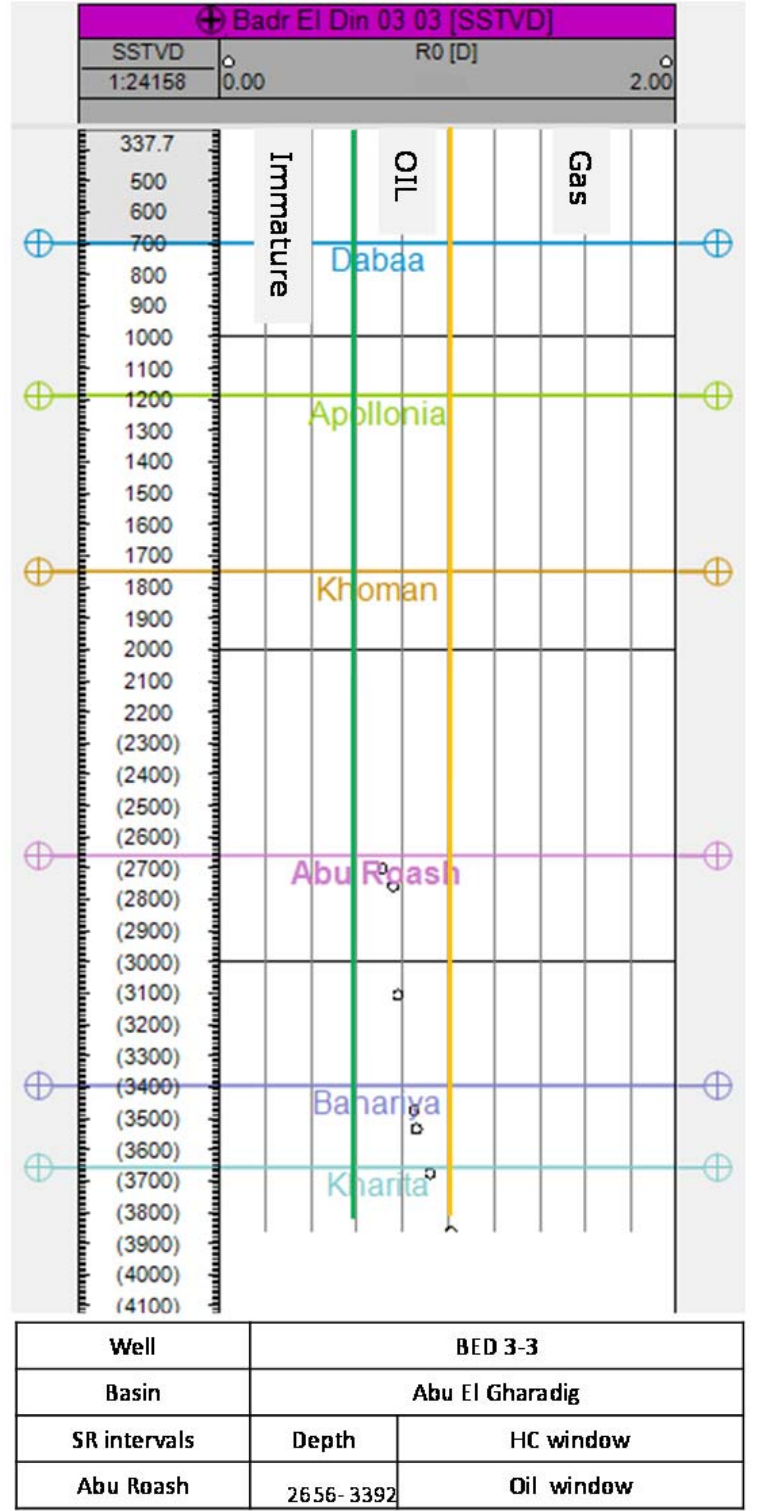

Fig. 22: Thermal maturity of BED3-3 well. 
Shale oil and gas prospectivity of the northern Western Desert

\begin{tabular}{|c|c|c|c|l|}
\multicolumn{4}{c|}{ Abu El Gharadig Basin } \\
\hline well & depth & R0 & SR interval & HC window \\
\hline Sit 2-1 & 2245 & 0.52 & Abu Roash G & Immature \\
\hline BED 3-10 & 3170 & 0.66 & Abu Roash F & Oil window \\
\hline BED 17-1 & 2800 & 0.62 & Abu Roash F & Oil window \\
\hline \multirow{3}{*}{ sit 4-1 } & 2292 & 0.52 & Abu Roash A & Immature \\
\cline { 2 - 5 } & 2456 & 0.56 & Abu Roash F & Immature \\
\cline { 2 - 5 } & 2562 & 0.59 & Abu Roash G & Immature \\
\hline \multirow{2}{*}{ sit 7-1 } & 2750 & 0.62 & Abu Roash G & Oil window \\
\hline
\end{tabular}

Fig. 23: Thermal maturity of selected well samples in Abu Gharadig Basin.

The liptinite macerals mostly consist of fresh or brackish water algal phytoclasts (20\%), with $10 \%$ marine dinocysts (classifications are based on Stach et al. (1975) and Bostick (1979)). The relative abundance of these algal phytoclasts indicates fluvial to shallow marine depositional environments. This is consistent with the conclusions of Bayoumi (1994), who suggested that the Abu Roash-E Member is made up of prograding, fluvially-supplied mouth bars deposited in a bay or lagoon.

The maceral group is equivalent to the keroginite (liptikeroginite) and liptinite (autochthonous and detrital) phytoclast groups of Massoud and Kinghorn (1985), i.e. mesoliptinite kerogens with oil and gas source potential of Rahman and Kinghorn (1995). These phytoclasts, which consist of phytoplanktonics (particularly algae), makeup the main organic components of types I and II kerogens and accumulate in marine, lacustrine, lagoonal and terrestrial environments. They are characterized by intermediate $\mathrm{H}$ and $\mathrm{O}$ contents and have a high oil and gas potential. This potential was confirmed by the results of RockEvalpyrolysis; the hydrogen index (HI) ranges from 201 to $337 \mathrm{mg} \mathrm{HC} / \mathrm{g}$ TOC (Fig. 24), and the genetic potential $(\mathrm{Pg})$ varies from 3.76 to $6.59 \mathrm{~kg} \mathrm{HC} /$ ton rock, indicating a good and effective source rock.

Fig. 24. Kerogen type of different source rock intervals in Abu Gharadig Basin.

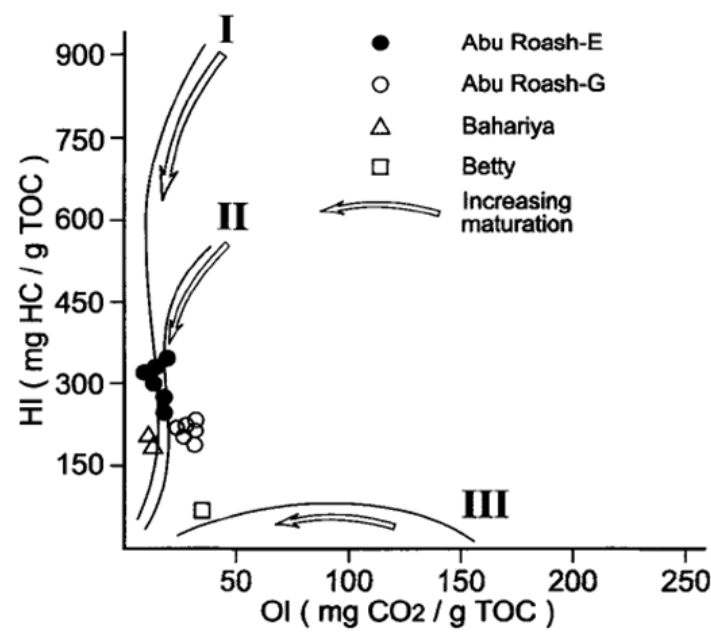

\section{CONCLUSIONS}

Screening of the geochemical data for Abu Roash source rock bearing interval in Shoushan and Abu Gharadig basins shows fair to high TOC values and kerogen type II and III. The strata lie in the immature to oil window in Shoushan Basin, whereas in Abu Gharadig Basin they lie in the oil/gas window. The Khatatba source rock has higher TOC values, sometimes up to $7-8 \mathrm{wt} \%$, with kerogen type II/III. In Shoushan Basin, it lies in a range from gas window to overmature window, meanwhile in Abu Gharadig Basin, it lies mainly in the overmature window and in some localities in the gas window. 
Soliman, et al.

Considering the higher price of oil rather than gas, source rocks of kerogen type II in the oil hydrocarbon window are mostly preferred than being located in the gas window. Source rocks of kerogen type III are less preferred for their lower productivity and the possibility to generate just gas when being matured.

Out of the studied dataset, Abu Roash Formation in Abu Gharadig Basin has higher potential as a shale oil and gas hydrocarbon play. Additional special analyses are required to reanalyze well cuttings geochemically and lithologically. To carry out the detailed Rock Eval pyrolysis for well cuttings, it should not be contaminated with the oil-base mud. Mechanical analysis will show intervals with the best clay content that will identify the successful intervals for the hydraulic fracturing process.

As the route work in the shale oil and gas exploration, the available data were studied and defined the Abu Roash Formation in Abu Gharadig Basin as possible shale oil and gas sweet spot. The proposed next action is to drill a vertical well in the defined area. Then, to drill several horizontal wells from the same vertical entry. Then, applying the hydraulic fracturing process for the best-defined intervals. Production tests for the gas, oil and condensate will define the economic value of the play and its way ahead.

\section{REFERENCES}

Abd El-Gawad E. A., Mousa D. A., Lotfy M. A., and El-Shorbagy A. I. (in press): Origin of Bahariya oil in Salam oil field, Western Desert- Egypt. Egyptian Journal of Petroleum, available online 18 October 2017, DOI: 10.1016/j.ejpe.2017.09.003.

Abdel-Gawad, E. A., Philip, R. P., and Zein El-Din, M. Y., (1996): Evaluation of possible source rocks in Faghur-Siwa Basin, Western Desert, Egypt. Proc. $13^{\text {th }}$ Petroleum Exploration and Production Conf. (EGPC), Cairo. 1, 417-432.

Abdel-Kireem, M. R., A. M. Samir, and M. I. A. Ibrahim, (1995): Upper Cretaceous planktonic foraminiferal zonation and correlation in the northern part of the Western Desert, Egypt: Neues Jahrbuch für Geologie und Paläontologie Abhandlungen, 198, 329-361.

Abdel-Kireem, M. R., A. M. Samir, E. Schrank, and M. I. A. Ibrahim, (1993): Cretaceous palaeoecology, palaeoclimatology and palaeogeography of the northern Western Desert, Egypt, in U. Thorweihe and H. Schandelmeier, eds., Geoscientific research in northeast Africa: Balkema, Rotterdam, The Netherlands, 375-380

Abdel-Kireem, M. R., and M. I. A. Ibrahim, (1987): Late Cretaceous biostratigraphy and palaeobathymetry of the Betty Well No. 1, Western Desert, Egypt, in G. Matheis and H. Schandelmeier, eds., Current research in African earth sciences: Balkema, Rotterdam, Netherlands, 1157-1188.

Awad, G. M., (1984): Habitat of Oil in Abu Gharadig and Faiyum Basins, Western Desert, Egypt. AAPG Bull., 68, 564-573

Awad, M. A., (2008): Geodynamic Evolution and Petroleum System of Abu Gharadig Basin, North western Desert, Egypt. Ph. D Aachen univ., Netherland, 239 p.

Baskin, D. K., (1997, Atomic WC ratio of kerogen as an estimate of thermal maturity and organic matter conversion. AAPG Bull., 91(9), 1437-1450.

Bayoumi, T., (1994): Synsedimentary tectonics and distribution of Turonian sandstone reservoirs, Abu Gharadig basin, Egypt. Proc. $12^{\text {th }}$ Petroleum Exploration and Production Conf. (EGPC), Cairo, I, 351367.

Bostick, N. H., (1979): Microscopic measurement of the level of catagenesis of solid organic matter in sedimentary rocks to aid exploration for petroleum and to determine former burial temperatures: A review. SEPM Spec. Publ., 26, 17-43.

Dahi, M., and Shahin, A. N., (1992): Paleozoic rocks distribution and hydrocarbon potential in the Western Desert, Egypt $(2,56-78)$. Paper presented at the $11^{\text {th }}$ Exploration and Production Conf., Egyptian General Petroleum Corporation, Cairo.

Darwish, M., El-Azabi, M. H., Eid, A. A. and Moussa, S., (2000): Hydrocarbon Habitat of some Mesozoic sedimentary basins, Onshore West Nile Delta, Egypt. $5^{\text {th }}$ Inter. Conf. Arab World (GAW), Cairo Univ. 


\section{Shale oil and gas prospectivity of the northern Western Desert}

Dolson, J. C. Shann, M. V. Matbouly, S. Hammouda, H. and Rashed, R., (2000): Egypt in the next millennium: petroleum potential in offshore trends. Proc. Mediterranean Offshore Conf., Alexandria, 109-131.

Douban, A. F., (1996): Basin Analysis and hydrocarbon potentiality of Matruh Basin, North Western Desert, Egypt. Proc. $3^{\text {rd }}$ Int. Conf. Arab World (GAW), Cairo Univ., 595-624.

EGPC, (1992): Western Desert, oil and Gas fields, A comprehensive overview, $11^{\text {th }}$ EGPC Conf., Cairo, 1, 4310.

El Beialy, S. Y., (1994): Palynostratigraphy and palynofacies analysis of some subsurface Cretaceous formations in the Badr El Dein (Bed 1-1) borehole, North Western Desert, Egypt: Neues Jahrbuch für Geologie und Paläontologie Abhandlungen, 192, 133-149.

El Beialy, S. Y., (1995): Datation and palaeoenvironmental interpretation by microplankton and miospore assemblages of the Razzak Oil Field sediments, Western Desert, Egypt: Geobios, 28, 663-673.

Guiraud, R., R. M. Binks, J. D. Fairhead and M. Wilson (1992): Chronology and geodynamic setting of Cretaceous-Cenozoic rifting in West and Central Africa. Tectonophysics, 213, 227-234.

Hendy, H., S. Gouda and L. Ghanem, (1992): Structural styles revealed by 3-D seismic data in the Abu Gharadig Basin, Badr El Din and Sitra lease areas, Western Desert, Egypt. Proceedings of the 11th Petroleum Exploration and Production Conference, Cairo, (1992): Egyptian General Petroleum Corporation, 2, 20-38.

Ibrahim, M. I. A., (1996): Aptian-Turonian palynology of the Ghazalat-1 well (GTX-1), Qattara Depression, Egypt: Review of Palaeobotany and Palynology, 94, 137-168.

Jenkins, D. A., (1990): North and Central Sinai. In Said, R. (Ed.), Geology of Egypt, Balkema, Rotterdam, 361-380.

Keeley, L. M., and Wallis, R. J., (1991): The Jurassic system in northern Egypt, II. Depositional and tectonic regimes. 'Review Journal of Petroleum Geology, 14, 49-64.

Khaled, K. A., (1999): Cretaceous source rocks at Abu Gharadig oil and gas field, North Western Desert, Egypt. Journal of Petroleum Geology, 22(24) 377-395.

Klitzsch, E., (1986): Plate tectonics and cratonal geology in north-eastern Africa (Egypt, Sudan). Geologische Rundschau, 75, 755-768.

Klitzsch, E., (1990): Paleozoic. In Said, R. (Ed.), Geology of Egypt (393-406), Balkema, Rotterdam.

Maky, A. B. F. and Ramadan, M. A. M. (2008): Nature of organic matter, thermal maturation and hydrocarbon potentiality of Khatatba Formation at East Abu-Gharadig Basin, North Western Desert, Egypt. Australian Journal of Basic and Applied Sciences, 2(2), 194-209.

Metwalli, M. H. and Abdel-Hadi, Y. E., (1975): The significance of the variation of crude oil gravities of some oil fields in the Northern Western Desert, A. R. Egypt. 9th Arab Petroleum Congress, Dubai, 113(B-3), 1-10.

Metwalli, M. H. and Abdel-Hady, Y. E., (1973): Tectonic analysis of the subsurface sedimentary succession in Alamein Field, Northern Western Desert, A. R. Egypt. Desert Inst. Bull., A. R. E., 23(2), 271-284.

Metwalli, M. H., Saad, M. K. and Ali, T. A., (1999): The Significance of porosity on the reservoir quality of the Upper Bahariya Clastics, Meleiha Oil Field area, North Western Desert, Egypt. Proc. 4th Int. Conf. Arab World (GAW), Cairo Univ., 924-935.

Metwalli F. I. and Pigott John D., (2005): Analysis of petroleum system criticals of the Matruh-Shushan Basin, Western Desert, Egypt. Petroleum Geoscience, 11; 157-178. doi: 10.1144/1354-079303-593

Moustafa, A. R., (2008): Mesozoic-Cenozoic basin evolution in the northern Western Desert of Egypt. The Geology of East Libya. 3. 29-46.

Moustafa A. R., A.Saoudi, Moubasher, A., Ibrahim, I. M., Molokhia, H., and Schwartz, B., (2003): Structural setting and tectonic evolution of the Bahariya Depression, Western Desert, Egypt. GeoArabia, 8(1), 91-124.

Moussa, H., (1986): Evolution of the sedimentary basins of the northern Western, Egypt (pp. 66-84). Paper presented at the $8^{\text {th }}$ Exploration and Production Conf., Egyptian General Petroleum Corporation, Cairo.

Parker, J. R., (1982): Hydrocarbon Habitat of Western Desert, 6th EGPC Conference, Cairo, 1-8P. 
Soliman, et al.

Peters, K. and Cassa, M., (1994): Applied source rock geochemistry. In Magoon, L. B. and Dow, W. G. eds., 1994, The petroleum system from source to trap: AAPG Memoir 60, 93-117.

Ramadan, M. and Kinghorn, R. R. F., (1995): A practical classification of kerogens related to hydrocarbon generation. J. Petrol. Geol., 18, (1), 91-102.

Ramadan, F.S., Metwalli, F.I., El-Khadragy A.A., and Afify, W, (2012): The subsurface geology and source rocks characteristics of some Alam El Bueib reservoirs In Tut Oil Field, North Western Desert, Egypt. J. Applied Sci. Res., 8(11): 5388-5409, ISSN 1819-544X

Said, R., (1990): Geology of Egypt (439-450), Balkema, Rotterdam.

Sestini, G., (1995): Egypt. Regional petroleum geology of the world, part II: Africa,America, Australia and Antarctica. In Kulke, H. (Ed.), (Vol. Beiträge zur regionalen Geologie der Erde, 22, 66-87, Gebrüder Bornträger Verlagsbuchhandlung, Stuttgart.

Shalaby M. R., Abdullah W. H., and Abu Shady, A. N., (2008): Burial history, basin modeling and petroleum source potential in the Western Desert, Egypt. Bulletin of the Geological Society of Malaysia 54, 103 - 113, doi: 10.7186/bgsm2008017

Shahin, A. N., and Shehab, M. M., (1988): Undiscovered hydrocarbon reserves and their presentation time limits in West Qarun area, Abu Gharadig basin, Western Desert, Egypt, 2, 134-163. Paper presented at the $9^{\text {th }}$ Petroleum Exploration and Production Conf., Egyptian General Petroleum Corporation, Cairo.

Stach, E., Mackowesky, M. Th., Teichmuller, M., Taylor, G. H., Chandra, D., and Teeichmuller, R., (1975): Coal petrology. Gebruder Borntraeger Berlin, Stuttgart, a text book.

Sultan, N., and Abd El Halim, M., (1988): Tectonic framework of Northern Western Desert, Egypt and its effect on hydrocarbon accumulations. Paper presented at the 8th Exploration and Production Conference, Egyptian General Petroleum Corporation, Cairo. 20-23.

Tissot, B. P., Durand, B., Espitalie, J., and Combaz, A., (1974): Influence of nature and diagenesis of organic matter in formation of petroleum. AAPG Bull., 58, 499-506.

Van Krevelen, D. W., 1961, Coal. New York, Elsevier Science, pp. 514.

Waly, M., Allard, A. and Abdel-Razek, M., (2001): Alamein basin hydrocarbon expulsion of organic matter in formation of petroleum. AAPG Bull., 58, 499-506.

Waples, D. W., (1994): Modeling of sedimentary basins and petroleum systems. In Magoon, L.B. and Dow, W. G. eds., (1994): The petroleum system from source to trap: AAPG Memoir 60, 307-322.

Younes, M.A., (2005): Petroleum geochemistry and potential source rock correlation in the Shushan Basin, north Western Desert, Egypt. Petroleum Sci. and Tech., 23, 507-536.

Zein El-Din, M. Y., and El-Hamzy, A. A., (1980): On the source rock potentialities of the Jurassic sediments, Western Desert, Egypt. 8th IGES Hannover Accepted Abstract. P. 106

Zein El-Din, M. Y., Matbouly, S., Moussa, S. and Abdel-Khalek, M., (1990): Geochemistry and oil-oil correlation in the Western Desert, Egypt. EGPC 10th Petroleum Exploration and Production Conference, Cairo. Unpaged.

Zobaa, M. K., Oboh-Ikuenobe, F. E. and Ibrahim, M. I., (2011): The Cenomanian/Turonian oceanic anoxic event in the Razzak Field, north Western Desert, Egypt: Source rock potential and paleoenvironmental association. Marine and Petroleum Geology. 28, 1475-1482. 
Shale oil and gas prospectivity of the northern Western Desert

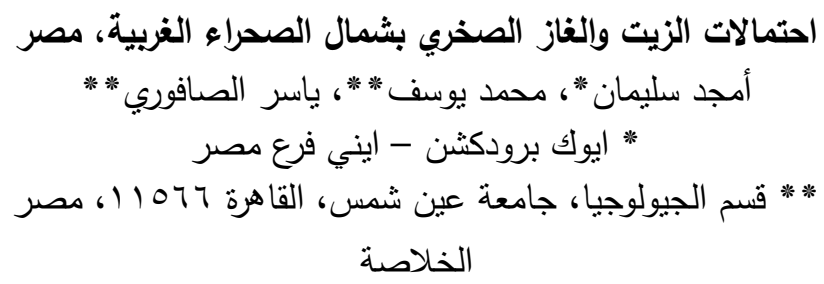

حظيت الصحراء الغربية بالعديد من الدراسات والأبحاث الجيولوجية منذ تحقيق أول اكتثاف بترولي عام 1979 وحتى الآن،

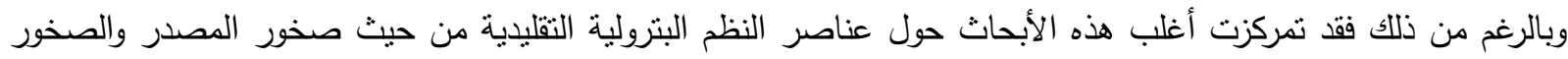
الحاجزة والخزانات، إلا أن هذا البحث يشمل إعادة تقييم للعديد من النطاقات الجيولوجية والأحواض التركيبية من منظور النئ النظم

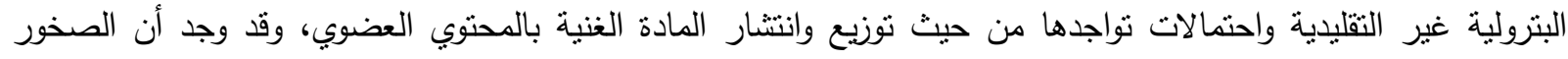

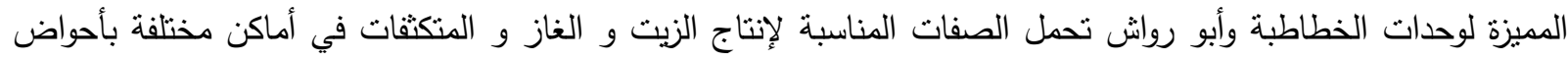
الترسيب للصحراء الغربية بناء علي محتواها العضوي ونوع الكيروجين و درجة نضجها الحراري، و قد نم عرض الرسم البياني

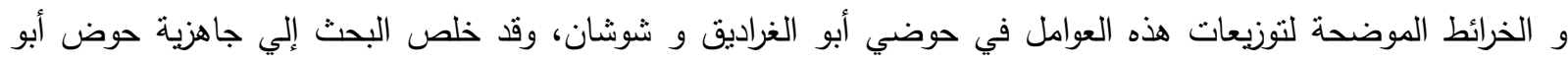
الغراديق لإنتاج الزيت والغاز الصخري من صخور الطفلة المميزة لمتكون أبو رواش. الكلمات الدالة: غير تقليدي، زيت صخري، غاز صخري، صخور المصدر ، الصحراء الغربية، حقل أبو الغراديق، متكون أبو

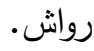

